\begin{tabular}{|c|c|c|c|c|c|}
\hline \multirow[b]{2}{*}{ Group } & \multirow{2}{*}{$\begin{array}{l}\text { No. of } \\
\text { Patients }\end{array}$} & \multicolumn{2}{|c|}{$\begin{array}{l}\text { Mean Creatinine } \\
\text { Clearance }(\mathrm{ml} / \mathrm{min})\end{array}$} & \multicolumn{2}{|c|}{$\begin{array}{c}\text { Mean Blood Pressure } \\
\text { (Lying) (mm Hg) }\end{array}$} \\
\hline & & Initial & Final & Initial & Final \\
\hline $\begin{array}{l}\text { I.C.C. }<30 \mathrm{ml} / \mathrm{min} \\
\text { I.C.C. } 31-60 \mathrm{ml} / \mathrm{min} \\
\text { I.C.C. }>60 \mathrm{ml} / \mathrm{min} \\
\text { All patients }\end{array}$ & $\begin{array}{l}18 \\
14 \\
37 \\
69\end{array}$ & $\begin{array}{r}15 \cdot 2 \\
45 \cdot 7 \\
102 \cdot 5 \\
72 \cdot 3\end{array}$ & $\begin{array}{l}21 \cdot 3 \\
47 \cdot 6 \\
93 \cdot 8 \\
69 \cdot 2\end{array}$ & $\begin{array}{l}187 / 119 \\
194 / 122 \\
180 / 116 \\
185 / 118\end{array}$ & $\begin{array}{l}155 / 90 \\
157 / 93 \\
140 / 86 \\
148 / 88\end{array}$ \\
\hline
\end{tabular}

intrinsically harmful effect of beta-blockade on renal function can be inferred. It is the general experience of any unit treating hypertensive patients with renal functional impairment that transient reduction in renal function may occur during the early stages of effective blood pressure control. This usually returns to the same level or possibly increases above the initial value. The increased peripheral resistance that can oocur with beta-blockade might be shared by the renal vasculature. Should reduction in renal function occur after the institution of betablockade this may be an indication for the addition of a peripheral dilator such as hydrallazine.

We intend to describe fully in future publications our experience of the treatment of hypertension in the presence of renal disease using propranolol. This will subsubstantiate our earlier findings ${ }^{1}$ that there is no indication for a reduction of propranolol dosage with reduced renal function.-We are, etc.,

\section{Institute of Urology}

F. D. THOMPSON

St. Peter's Group of Hospitals,

A. M. JOEKES

St. Peter's Gro
London W.C.2

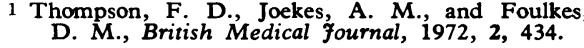

\section{Autoimmune Haemolytic Anaemia in Ulcerative Colitis}

SIR,-We would like to report an interesting case of autoimmune haemolytic anaemia with an antibody showing rhesus specificity in a patient with relapsing ulcerative colitis. The anaemia apparently responded to steroid treatment of the colitis.

The patient, a 23-year-old nulliparous woman known to have colitis, was admitted on the present occasion with an exacerbation. Her haemoglobin concentration was $9.8 \mathrm{~g} /$ $100 \mathrm{ml}$, mean corpuscular volume $119 \mathrm{pg}$, and reticulocyte count $7 \%$. The blood film showed many spherocytes and the direct antiglobulin (Coombs) test was strongly positive. Serum folate $(1.6 \mathrm{ng} / \mathrm{ml})$ and red cell folate $(131 \mathrm{ng} / \mathrm{ml})$ levels were both low. She was treated with prednisone and folic acid.

The positive antiglobulin test showed IgG specificity and her serum contained antibody of mixed specificity, but an eluate of her red cells contained an antibody with anti-ê specificity. On treatment the haemoglobin rose to normal, the reticulocyte count fell to $3 \%$, and the antiglobulin test became negative. The serum, however, still contained antibody now appearing to have some anti-e specificity. Her probable rhesus genotype was cde/cole and this is consistent with the antibody being an autoantibody.

There are several reports in the literature ${ }^{1-5}$ describing the presence of positive direct antiglobulin tests in a total of eight patients with ulcerative colitis. Only a few of these showed active haemolysis and only two of them showed any degree of rhesus specificity (in one patient an anti-ê plus $f$ from a red cell eluate and in another patient an anti-e in the serum). It is important to report such cases, which may help to elucidate the "aetiology and pathogenesis of this autoimmune haemolytic anaemia which does not have to be classified as idiopathic." 6

We would like to thank Dr. Sheila Worlledge for helpful discussion about this patient and Dr. T. $M$. Chalmers for permission to report the case. -We are, etc.,

\section{Department of Haematology,}

A. H. Goldstone Addenbrooke's Hospital, Cambridge

1 Lorber, M., Schwartz, L. I., and Wasserman, L. R., American fournal of Medicine, 1955, 2 Balint, J. A., Hammack, W. J., and Patton, T. B., Balint, J. A., Hammack, W. J., and

Fong, S., Fudenberg, H., and Perlmann, P. Vox Sanguinis, 1963, 8, 668.
Gastoldi, F., et al., Rivista di Emoterapia ed Emoterapia ed Immunoematologia, 1964, Rivista di Emoterapia ed Immunoematologia, 1964, 11, 43. p. 826. London, Churchill, 1967.

\section{Urethral Prolapse in Children}

SIR,-YYour leading article (4 May, p. 240) perhaps makes this condition sound more complicated than it really is. From an experience of some 25 patients under the age of 8 may I suggest two points? (1) The diagnosis is usually easily made by passing a urethral catheter-prolapse is the only tumour which symmetrically surrounds the catheter. (2) Treatment is best done as an outpatient, avoiding the psychogenic trauma of separation in a frightened young child. Under general anaesthesia (so rapidly eliminated today) two stitches (Dexon (polyglycolic acid) may be best) are inserted through normal urethra at right angles to one another. The prolapsed tissue distal to the sutures is then excised. The "cross" is then picked up with forceps and converted into four stitches, which can be tied with no fear of retraction of the mucosa.

I believe it is unwise to leave a catheter in the bladder as this only leads to infection. I have not found it necessary to catheterize subsequently for retention and I am not aware of urethral stricture developing subsequently (though my follow-up is not complete).-I am, etc.,

Royal Free Hospital,

Charles P. Douglas Royarpool Road Branch
London N.1

\section{Photosensitivity to Pyrimethamine?}

SIR,-I wish to report an apparent photosensitivity reaction to pyrimethamine (Daraprim). The Committee on Safety of Medicines has had only one similar notification, in a male of unknown age who was given a course of pyrimethamine. He deGastoldi, F., et al., Rivista di Emoterapia ed veloped a photosensitivity rash 10 days after taking his first tablet.

My patient was a 9-year-old boy of English parents who arrived by air in Lagos during March 1974. At $23.00 \mathrm{hr}$ that day he was given one 25-mg Daraprim tablet. At $17.00 \mathrm{hr}$ the following day he developed a pink, confluent, macular, nonpruritic rash over his cheeks, forearms, and legs which corresponded exactly with those areas exposed to the sun. There was no malaise. The rash disappeared overnight but recurred on the third day following exposure to the sun. It again disappeared overnight and reappeared on the fourth day following exposure to the sun. On the fifth day there was no rash. He had taken pyrimethamine on many occasions previously, though this tablet was the first of his present course. He had never before had a skin rash and had no known drug or other sensitivities. There was no family history of drug or other sensitivities. He was taking no other drugs.

Wellcome-Lepetit (Nigeria) Ltd. analysed the remaining tablets from the packet and tablets from their quality-control stock and were unable to detect any deviation from their standard product.-I am, etc.,

Estate Clinic,

Stephen A. Craven Ikeja, Nigeria

\section{Fenticlor, Actinic Reticuloid, and} Antihistamines

SIR,-In the article "Diseases of the Skin: Acne Vulgaris" (15 December 1973, p. 667), Dr. W. J. Cunliffe suggests fenticlor as a suitable topical antimicrobial agent in treatment. Fenticlor causes photocontact dermatitis $^{1}$ and two cases of chronic dermatitis from persistent photosensitivity ${ }^{2}$ have followed its incorporation into a hair cream in the United Kingdom. Except for the absence of two chlorine molecules, fenticlor is identical with bithionol, ${ }^{3}$ known to cause distressing persistent photodermatitis which forces the sufferer to live a confined indoor life. ${ }^{4}$ Fenticlor and bithionol cannot be imported into Australia without Commonwealth authority, and the use of bithionol in consumer goods in the U.S.A. and Canada is restricted by government legislation.

The term "actinic reticuloid" describes a chronic dermatosis associated with severe photosensitivity and histological resemblance to lymphoma. Ive et al. ${ }^{5}$ in the original report of this condition suggest a relationship with the chronic photodermatitis caused by photoallergens such as bithionol and fenticlor. Wilkinson ${ }^{6}$ described a case of actinic reticuloid which first developed in 1969 but in which sensitivity to tetrachlorosalicylanilide, a halogenated salicylanilide related to fenticlor and bithionol, had been diagnosed in 1960. A direct causal relationship between actinic reticuloid and contact photoallergens has not been established, though such a relationship must be suspected. Sneddon ${ }^{7}$ described a case of actinic reticuloid which may have developed into a true lymphoma.

It has been proposed that persistent light reactions following the use of contact photoallergens are caused by the retention of those photoallergens in the dermal layer of skin for long periods. ${ }^{8}$ This conoept might con- 
ceivably be playing a part in the aetiology of other disease entities, ${ }^{9}$ and halogenated salicylanilides and related compounds may not be the only drugs retained in this manner. ${ }^{10}$

Dr. R. H. Champion, in the article "Diseases of the Skin: Drug Therapy of Urticaria" (22 December 1973, p. 730) states that "antihistamine drugs may, if necessary, be continued for months or years with safety." How can he be sure of this? How can we be certain that any of the photosensitizing drugs which cover a wide therapeutic range and include several antihistamines are not retained in the dermis for long periods, eventually playing a part in the production of actinic reticuloid in susceptible subjects? Promethazine, an antihistamine, and chlorpromazine, a tranquillizer, two phenothiazine derivatives, may cause persistent photodermatitis which depends upon concomitant oral administration and external application. ${ }^{11-13}$ The active photocontact sensitizers cause multiple crosssensitivities ${ }^{14}$ and it is conceivable that one or several photosensitizing drugs retained in the dermis might be immunologically activated by an external powerful sensitizer such as fenticlor, leading to actinic reticuloid.-I am, etc.,

St. Peters,

JOHN N. BURRY

South Australia

1 Burry, J. N., Archives of Dermatology, 1967, 95, Ramsay, C. A., and Crow, K. D., personal com3 munication. 97, 497.

4 Hillson, O. F., and Baughman, of Dermatology, 1963, 88, 409 .
Ive, F. A., et al., British fournal of Dermatology, Ive, F. A., et al.

6 Wilkinson, D. S., British Fournal of Dermatology, $1972,87,397$.

7 Jensen, N. E., and Sneddon, I. B., British fournal of Dermatology, 1970, 82, 287.

Willis, I., and Kligman, A. M., fournal of Investigative Dermatology, 1968, 51, 385

Burry, J. N., New England fournal of Medicine, 1969, 281, 620

Cox, A. J., and Marich, K

Dermatology, 1973, 108, 655, of Investigative Dermatology, 1955, 24, 345 .

12 Calnan, C. D., and Frain-Bell, W., Transactions of the St. Fohn's Dermatological Society, 1962, of the St. Fohn's Dermatological Society, 1962, tion.
48.

13 Fisher, A. A., Contact Dermatitis. London, 14 Himpton, 1967.

Dermatology, ed. A. Rook, D. S. Wilkinson, and F. D. Ebling, Oxford, Blackwell, 1972.

\section{Looking after Schizophrenics}

SIR,-Your leading article (4 May, p. 236) is to me a sad one as you seem to support the view that our old large mental hospitals should not be closed if only because of all the schizophrenics still needing treatment in them. But is the present chronicity rate really necessary? The trouble may be that many schizophrenic patients are being inadequately treated at present. For instance, drugs remedying the affective component of a schizophrenic illness, such as lithium, trimipramine and Parstelin (tranylcypromine+ trifluoperazine), are not being used enough, more electric convulsive therapy (E.C.T.) should often be given in early cases, and insulin sopor and modified narcosis with further intensive E.C.T. may be needed in resistant obsessive patients.

In $1961^{1}$ and again in $1965^{2}$ we showed at St. Thomas's Hospital that over $80 \%$ of schizophrenics treated actively with modified insulin, E.C.T., and chlorpromazine were at home in a two-year follow-up and mostly at work. And this needed only an average hospital treatment stay of six weeks. In $1972^{3}$ we published the results of treatment of 74 schizophrenic and schizoaffective patients, many considered chronic, who were given modified narcosis, phenothiazines, intensive E.C.T., and the combined antidepressants all together, and many were helped who had been sent for considered leucotomy. Fiftytwo of the 74 patients were still helped.

On retirement from St. Thomas's in 1972 I was able to re-establish a narcosis ward in a psychiatric nursing home and today, among other patients, 25 often considered "chronic" schizophrenics have had the full combined narcosis and E.C.T. treatment with additional insulin sopor when needed. It has sometimes needed more than 20 E.C.T.s and over two months of narcosis to bring no less than 22 out of these 25 patients into remission. Five patients had been ill with schizophrenia for 10 years or more, eight for five years or more, and $\mathbf{1 2}$ for less than five years.

With a really skilled and intensive physical reatment approach there could be many fewer recent schizophrenics going into our old asylums and many are now recoverable in them.-I am, etc.,

London W.1

WILliaM SARGANT 1 Rohde, P., and Sargant, W., British Medical
fournal, 1961, 2, 67.
2 Kelly, D., and Sargant, W., British Medical
fournal, 1965, 2, 147.
3 Walter, C., Mitchell-Heggs, N., and Sargant, W.,
British fournal of Psychiatry, 1972, 120, 651. British fournal of Psychiatry, 1972, 120, 651.

\section{Confidentiality in Medicine}

SIR,- "Whatsoever I shall see or hear in the course of my profession ... I shall never divulge, holding such things to be holy secrets." On this Hippocratic principle many of us were taught and so have practised. Until recently the public were justified in expecting and respecting our ability to vouchsafe any statements made at consulta-

One of the few disadvantages of group practice is the fact that medical records are now largely kept in a central office to which ancillary workers have ready access. In my opinion the doctor is the patient's confidant and in order to remain so these notes must really not be so generally available to all and sundry, however discreet they may be. To my consternation the other day I learned that some of my colleagues actually encourage the perusal of their files by these very folk. It is surely a very grave matter that should be seriously considered by the profession. Some of our patients are beginning to ask, "Is everything confidential?" Years ago it was taken for granted and I think the decline in standards is sad. -I am, etc.

Guildford, Surrey

JOHN TAYLOR

Screening-G.P. or Family Planning Doctor?

SIR,-In taking the medical history in the ordinary family planning session factors come to light from time to time-such as a history of hepatitis, a familial history of diabetes, or the possibility of sickle-cell anaemia-in which laboratory investigation is desirable. Conditions requiring further investigation and treatment must be referred to the patient's general practitioner and, ideally, perhaps all such matters should be so referred. But this is often cumbersome, certainly delaying, and unfortunately not always followed through by every G.P. This raises the question who should be primarily responsible for such screening.

G.P.s have direct access to outpatient pathological services. I consider that family planning doctors to have an obligation to arrange certain screening investigations directly as an integral part of advice on oral contraception. If similar outpatient pathological facilities were available to them, provided these were used sensibly and only where indicated, I believe this would greatly improve the work of the family planning doctor and could relieve the load on the G.P. if this procedure is agreeable to him. Where direct referral to the G.P. is not done for any reason he should, of course, always be informed of the results.

It would be interesting and helpful to hear the views of G.P.s (and pathologists) on such direct screening being arranged routinely by the family planning doctor.-I am, etc.,

London N.W.3

N. Chisholm

\section{Encroachments on the Patient's Responsibility}

SIR,-There seems to be a tendency for doctors, and surgeons in particular, to accept responsibility for matters that are not primarily their own concern and, even more alarmingly, to exclude the patient in a somewhat dictatorial manner from any say or responsibility in the matter.

Two recent examples are the question of surgery and the birth control pill and the 10 -day rule for $x$-ray examinations. I suggest that it is the responsibility of the prescribing doctor to point out the risks and complications of the pill, and thereafter it is the patient's responsibility whether she takes it or not. While the reasons for the 10-day rule for $x$-ray examinations are appreciated, I see no reason why the patient should not be allowed to waive the rule herself by signing on the request form. To refuse to allow this is an alarming interference with a patient's independence and will cause unnecessary inconvenience and even anxiety.

There is an increased morbidity after surgery in overweight patients, cigarette smokers, etc. The next step could be to refuse these patients the right to surgery rather than the present system of giving strong advice and leaving the final decision to the patient. - I am, etc.,

Warwick Hospital,

R. F. N. DUKE Warwick

\section{Acute Brucellosis Presenting as Epididymo-orchitis}

SIR,-The letter (27 April, p. 221) by Dr. D. J. H. Payne prompts us to report an unusual presentation of acute brucellosis in which, happily, the serology was helpful.

A dairy farmworker, aged 32 years, presented to his general practitioner on 7 February 1974 with fever and signs of a right epididymo-orchitis. 